\title{
Boionautilus gen. nov. from the Silurian of Europe and North Africa (Nautiloidea, Tarphycerida)
}

\author{
VOJTĚCH TUREK
}

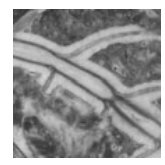

\begin{abstract}
Tarphycerids of the suborder Barrandeocerina are striking owing to the large size of the shell and similarity with the recent Allonautilus Ward \& Saunders, 1997. They are widely distributed in the Silurian rocks of Europe. They were originally classified within the genus Nautilus Linnaeus, 1758 but generic assignment remained questionable despite the detailed description and excellent illustration provided by Barrande in 1865. Species belonging to this group have been assigned to the genera Barrandeoceras Hyatt, 1884, Heracloceras Teichert, 1940, or Cumingsoceras Flower, 1950 but none of them is appropriate considering their morphology, phylogenetic trends and stratigraphic range. Therefore, a new genus Boionautilus is established here. An evolutionary trend is discerned, expressed especially in the tighter coiling of the shell - a transition from an evolute shell (gyroceracone at the beginning of the second whorl) with subelliptic cross section, to a slightly involute shell with a subtrapezoidal cross section. The dorsoventral diameter of the whorl increased more rapidly, and septa became more densely spaced. Boionautilus tyrannus (Barrande, 1865) is now known to occur in North Africa (Algeria, the Ougarta Range). Previously-mentioned finds in peri-Gondwanan sediments of the Carnic Alps are here rejected. Differences in the colour of septa and connecting rings in one exceptionally well-preserved specimen of this taxon from Algeria and one Bohemian specimen of B. sternbergi (Barrande, 1865) are remarkable and indicate high primary content of organic matter within the connecting rings. - Key words: Cephalopoda, Nautiloidea, Tarphycerida, new taxon, Silurian, Europe, North Africa.
\end{abstract}

TUREK, V. 2008. Boionautilus gen. nov. from the Silurian of Europe and North Africa (Nautiloidea, Tarphycerida). Bulletin of Geosciences 83(2), 141-152 (7 figures). Czech Geological Survey, Prague. ISSN 1214-1119. Manuscript received February 18, 2008; accepted in revised form April 25, 2008; issued June 30, 2008.

Vojtěch Turek, National Museum, Department of Palaeontology, Václavské náměstí 68, 11579 Praha l, Czech Republic; vojtech_turek@nm.cz

Within the markedly diverse Silurian fauna especially from the cephalopod limestones present in 13 stratigraphic levels in peri-Gondwanan Europe (Kříž 1998, Manda \& Kř́̌̌ 2007), the tarphycerids of the suborder Barrandeocerina form a minor but not insignificant group of nautiloids. Owing to these favourable circumstances, coupled with a very good state of preservation and the highly refined stratigraphy in the Prague Basin, the Bohemian Palaeozoic offers an exceptional opportunity for tracing evolutionary trends within some groups of Silurian cephalopods. The majority of species belonging to the Tarphycerida were described in the second half of the $19^{\text {th }}$ century (Barrande 1865-1877, Novák 1886). Barrande's illustrations served as a basis for establishing several new genera (Hyatt 1884, 1894; Foerste 1926). Attention to the Bohemian representatives of this group was again given in the last quarter of the $20^{\text {th }}$ century (Turek 1972, 1975, 1976; Dzik 1984; Stridsberg \& Turek 1997). The majority of species described in the $19^{\text {th }}$ century, however, have not yet been revised. These tarphycerids belong especially to the family Lechritrochoceratidae Flower in Flower \& Kummel 1950; others are included within the Ophioceratidae Hyatt, 1894 and Uranoceratidae Hyatt in Zittel, 1900. This report concentrates on revision of representatives of the last-mentioned family.

Large Silurian tarphycerids of the suborder Barrandeocerina, family Uranoceratidae resemble in their outer shell morphology the recent Nautilus Linnaeus, 1758, or more precisely, Allonautilus Ward \& Saunders, 1997. These tarphycerids originally assigned to the genus Nautilus have been reported from different parts of Europe (Hisinger 1829, 1831, 1837; Barrande 1865-1877; Blake 1882; Novák 1886; Heritsch 1929). The best-preserved specimens, the stratigraphical positions of which have been accurately determined, come from Central Bohemia and were originally described by J. Barrande. Different cephalopod workers assigned them, frequently with some uncertainty, to the genera Barrandeoceras Hyatt, 1884, Heracloceras Teichert, 1940, and Cumingsoceras Flower in Flower \& Kummel, 1950, occasionally also to Charactoceras Foerste, 1924, as can be seen in some labels attached to the Bohemian specimens in the collection of Schary stored at the Museum of Compara- 
tive Zoology, Harvard. Such a situation reflects not only the different taxonomic approaches of individual palaeontologists but also insufficient knowledge of the morphology of some of these genera. Therefore, the question concerning the systematic position of these tarphycerids is reopened here; variability, traceable phylogenetic trends within the genus, stratigraphic ranges of described species and geographic distribution are considered. While the occurrence of any species of Boionautilus in the Carnic Alps was not confirmed during my inspection of specimens figured by Hetritsch (1929), Boionautilus tyrannus (Barrande, 1865) was determined among those cephalopods coming from Silurian strata of peri-Gondwana - the Ougarta Range, Algeria. Differences in preservation of the internal structures in one specimen from this area as well as in another specimen coming from the Prague Basin are remarkable and demonstrate substantial primary differences in chemical composition of septa and connecting rings, indicating the need for a detailed study of the siphuncle of representatives of the Barrandeocerina.

Specimens studied come particularly from the collection of J. Barrande deposited in the National Museum, Prague (prefix NM-L) and the Schary collection stored at the Museum of Comparative Zoology, Harvard (prefix MCZ); some additional specimens collected by Schary are deposited in the Museum of Natural History, Vienna (prefix NHM). Other specimens at my disposal were collected over the last few decades especially by R. Horný, L. Zedník, Š. Manda and A. Č́́žek. Material from Gotland, Sweden is stored in the Swedish Museum of Natural History, Stockholm (prefix Mo).

\section{Systematic palaeontology}

Subclass Nautiloidea Agassiz, 1847

Order Tarphycerida Flower in Flower \& Kummel, 1950

Suborder Barrandeocerina Flower in Flower \& Kummel, 1950

Family Uranoceratidae Hyatt in Zittel, 1900

\section{Boionautilus gen. nov.}

Type species. - Nautilus bohemicus Barrande, 1865, Silurian, Přídolí, Pristiograptus transgrediens Biozone, Požáry Formation, Prague Basin, Bohemia. Since the lectotype of the type species has not yet been designated, specimen NM-L 29860, illustrated by Barrande (1865) on pl. 33, fig. 2, is selected herein. The specimen, figured here on Fig. 1A, B, comes from the locality Karlštejn.

Etymology. - According to the Celtic tribe (Boii, Lat.) that inhabited the territory of Bohemia and similarity to Nautilus.
Diagnosis. - Shell large, evolute to dorsally slightly impressed, laterally compressed, moderately to rapidly expanding. Body chamber occupies about a $1 / 4$ to $3 / 8$ of the whorl. Cross-section is subelliptic or subtrapezoidal with narrower ventral side. Sutures with broad lateral lobes, narrower ventral saddle and small dorsal lobe. Siphuncle narrow to moderately wide situated subcentrally, septal necks orthochoanitic, connecting rings moderately expanding within camerae in more advanced growth stages. Embryonic shell curved and large; length measured along the axis of the shell reaches 11 to $13 \mathrm{~mm}$. Surface of embryonic shell with fine longitudinal lirae. In later growth stages these lirae disappear and the shell is smooth or with slightly indicated ribs; hyponomic sinus deep. Retractor muscle scars situated ventrolaterally.

Discussion. - Proper generic assessment of these large tarphycerids is a problem persisting from the $19^{\text {th }}$ century. Owing to their similarity to recent Nautilus, tarphycerids were originally assigned to that genus. The first published illustrations of nautiloids assigned here to Boionautilus gen. nov. were given by Hisinger $(1831,1837)$ but were more artistic than precise. Illustrations of four new species belonging to this genus published by Barrande (1865), however, are excellent. Some additional species were described and well illustrated by Blake (1882) and Novák (1886).

Hyatt (1883-1884, p. 299) assigned four Bohemian species described by Barrande - Nautilus bohemicus, $N$. sacheri, $N$. sternbergi and $N$. tyrannus to his new genus Barrandeoceras. He was followed by, e.g., Whiteaves (1906), Heritsch (1929, 1930), Basse (1952), and Horný (1965). The generic name was applied with reservation also by Histon $(1998,1999)$ in the list of specimens figured by Heritsch (1929) from the Carnic Alps. Dzik (1984, in explanation to pl. 42) assigned them with reservation to Heracloceras Teichert, 1940, preferring to derive this genus from Charactoceras Foerste, 1924. Turek \& Marek (1986) classified these coiled nautiloids as Cumingsoceras Flower in Flower \& Kummel, 1950, a genus that, according to Dzik (1984), is synonymous with Uranoceras Hyatt, 1884.

Barrandeoceras Hyatt, 1884 (type species Nautilus natator Billings, 1859; Chazyan, Middle Ordovician) should be assigned according to Sweet (1964) to the family Barrandeoceratidae Flower \& Kummel, 1950, and by Dzik (1984) to the Tarphyceratidae Hyatt, 1884. The shell of the type species is much more longiconic than that of Boionautilus and also costate, and the body chamber is distinctly divergent and narrow. The siphuncle is narrow and tubular in all growth stages (Ulrich et al. 1942, Sweet in Moore 1964, Flower 1984); only distal ends of the othochoanitic septal necks are in contact with the connecting rings ventrally (Sweet in Moore 1964, fig. 271), a characteristic that may be taxonomically significant. In summary, Barrandeoceras 

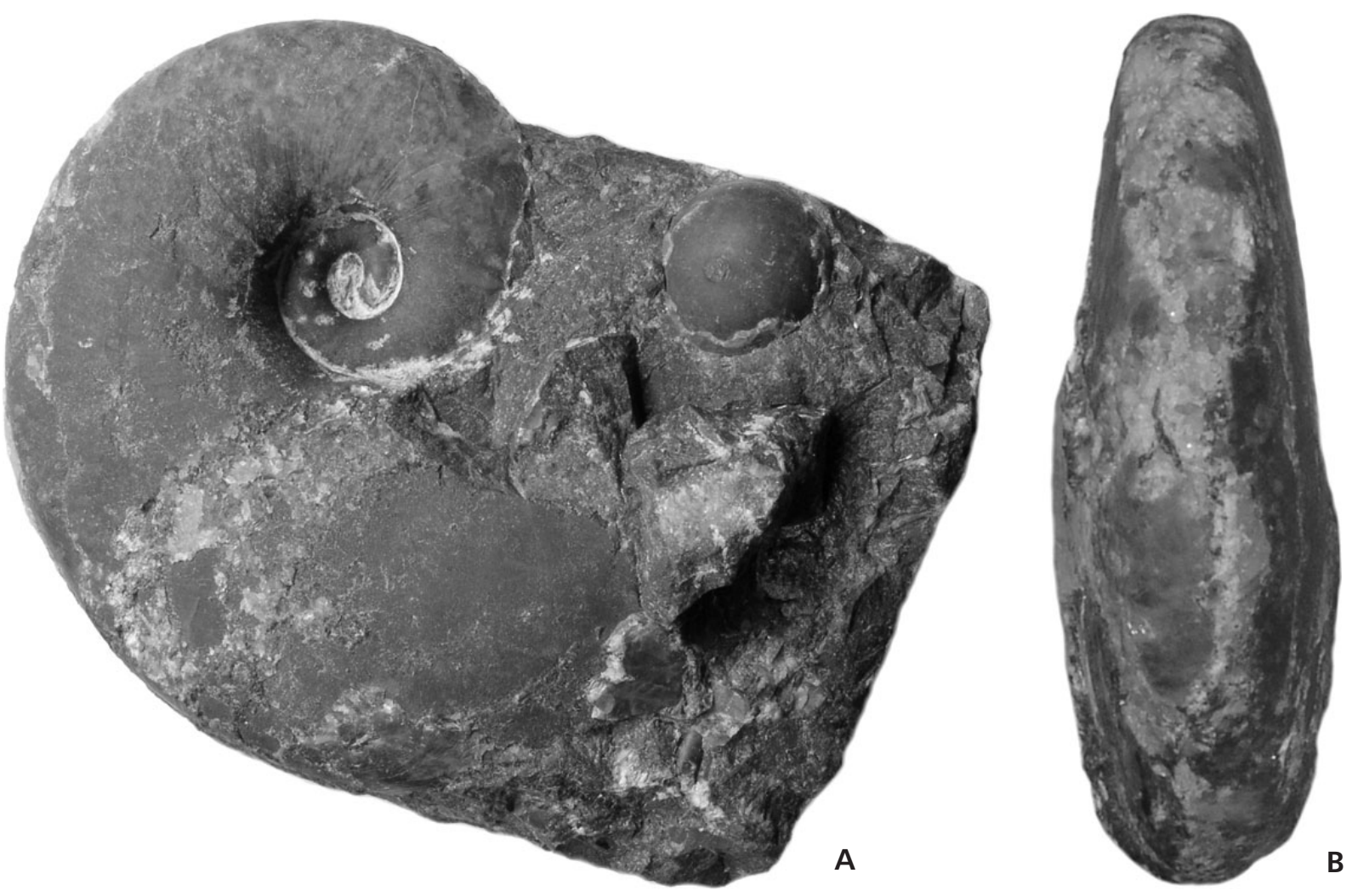

Figure 1. Boionautilus bohemicus (Barrande, 1865). • A, B - Karlštejn (Bohemia), Přídolí, Požáry Formation, Pristiograptus transgrediens Biozone. Almost complete specimen with preserved embryonic shell. Lateral and posterior views. Lectotype (designated herein), figured by Barrande (1865, pl. 33, fig. 2), NM-L 29860, × 0.9.

shows markedly different shell morphology from all Boionautilus species so that it is untenable to assign them to this Ordovician genus, which probably did not cross the Ordovician-Silurian boundary (see Kröger 2005).

Heracloceras Teichert, 1940 [type species Gyroceratites (Nautilus?) inelegans Meek, 1871; Middle Devonian, U.S.A., Ohio] is an insufficiently known genus. Information concerning the connecting rings, embryonic shell and muscle scars is missing. The shell of Heracloceras is loosely coiled with a remarkably long body chamber occupying half of the whorl and widely spaced septa; sutures with a low dorsal saddle (Sweet in Moore 1964, Zhuravleva 1974). A specimen of $H$. inelegans figured by Davis \& Mapes (1996) shows wide ribs ventrolaterally. The only known occurrence of Heracloceras is in Middle Devonian strata in North America. Paucity of knowledge of morphology, geographic and stratigraphic distribution prohibits tracing the phylogeny of this genus. As late Silurian representatives of Boionautilus gen. nov. followed an evolutionary trend resulting in a slightly involute shell and closely spaced septa, an intimate relationship between compared genera is improbable.

Cumingsoceras Flower in Flower \& Kummel, 1950 (type species Gyroceras elrodi White, 1882; middle Silurian, U.S.A., Indiana, Illinois) seems to be more closely related to the genus Boionautilus than the three genera mentioned above. Turek \& Marek (1986) assigned species described by Barrande (1865-1877) from Central Bohemia to this genus while Dzik (1984) synonymized Cumingsoceras Flower in Flower \& Kummel, 1950 with Uranoceras Hyatt, 1884. Comparison of these coiled nautiloids is difficult especially due to the lack of information concerning the siphuncle and muscle scars in Cumingsoceras.

The holotype of Gyroceras elrodi refigured by Foerste (1925) and Sweet in Moore (1964) is an internal mould of an adult part of a phragmocone (indicated by the large size and markedly shortened last camera), cut slightly obliquely to the medium plane. The shell diameter of the complete specimen is estimated to be $30 \mathrm{~cm}$. Although the preserved part of the shell is gyroconic, it is probable that the missing body chamber was in contact with the preceding whorl (see Foerste 1925, pl. 14, fig. 1). A similar type of coiling can be observed in some specimens of Boionautilus sternbergi figured by Barrande (1865) on pl. 37, figs 1, 3 and refigured here as Figs 2, 3D. However, the shell in Cumingsoceras is more rapidly expanded, less compressed, and with widely spaced septa -16 camerae in the last whorl. The number of septa in specimens of comparable size of Boionautilus is approximately double. Although the height 


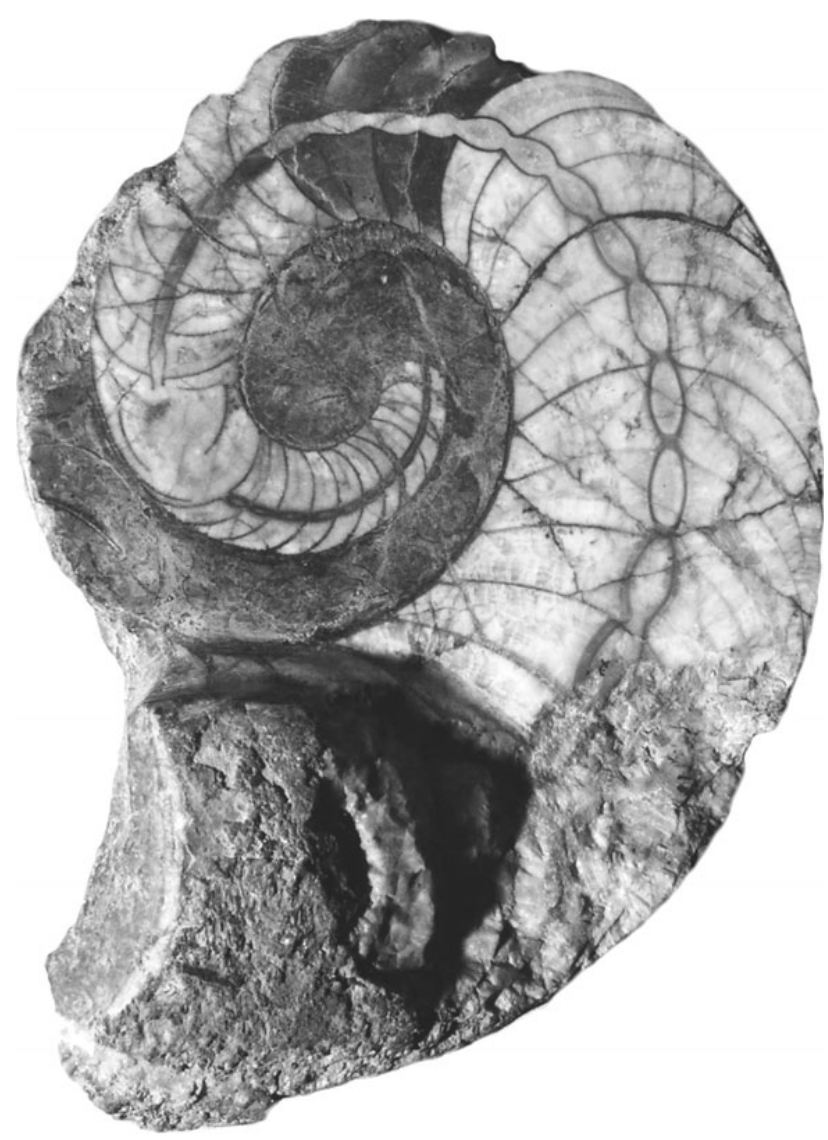

Figure 2. Boionautilus sternbergi (Barrande, 1865). Kosoř (Bohemia), Ludlow, Ludfordian, Kopanina Formation (Horizon with Ananaspis fecunda). Phragmocone, polished median section. The first half of the second whorl is loosely coiled. NHM 1876/B 0009/0478, $\times 0.9$.

of the camerae differs sometimes markedly even within one tarphycerid species, it seems probable that in this case, this feature was not properly evaluated. A dorsal saddle to the suture has not been reported. Fine longitudinal striae, in addition to undulating growth lines exhibiting a deep hyponomic sinus, have been reported in Cumingsoceras (Sweet in Moore 1964). In Boionautilus fine longitudinal striae occur only in embryonic and juvenile growth stages.

By comparison with Cumingsoceras, the genus Uranoceras is much better known. The type species of the latter, Cyrtoceras uranum Barrande, 1865 from the Silurian (lowermost Ludlow) of Bohemia has a thick, loosely coiled shell that in later growth stages diverges markedly from the spire. The siphuncle is wide, and connecting rings have a characteristic shape; they are cylindrical and strongly constricted immediately before the junction with the septal necks (Sweet in Moore 1964). Probably a little bit stratigraphically older, U. hercules (Winchell \& Marcy, 1865) from the upper Wenlock of North America is morphologically almost identical (based on observation of several specimens of $U$. hercules from the Racine Dolomites coming from F.H. Day's collection, deposited at the MCZ).
Although we do not know the shape of the connecting rings in Cumingsoceras, the very short septal necks, markedly shorter than in Boionautilus indicate a possibility that the siphonal segments in Cumingsoceras had the same shape as those of Uranoceras. Fine longitudinal striae are present on the surface of the shell in both genera.

When revising these cephalopods in detail, Dzik (1984) opined that both taxa (i.e. Cumingsoceras and Uranoceras) represent a single genus, and this is accepted herein. On the other hand, differences between Boionautilus and all the genera compared above are so essential that they substantiate the establishment of this new genus.

Barrande (1865-1867) described four Silurian tarphycerids assigned to Boionautilus: Nautilus sternbergi, $N$. sacheri, N. tyrannus and N. bohemicus. Imperfect coiling of the second whorl in the stratigraphically oldest Nautilus sternbergi is frequently observed in well-preserved specimens, and enables us to trace the roots of this genus within gyroceraconic forms. The Upper Ordovician Uranoceras? longitudinale (Angelin \& Lindström, 1880) from southern Sweden, revised in detail by Mutvei (1957), resembles the supposed common ancestor of Uranoceras and Boionautilus in having a similar morphology. A subcircular cross section of the ancestor passed into a subelliptic one and the ventrocentrally situated siphuncle shifted close to the axis of the shell, sometimes slightly dorsally from the centre. The cross section of the whorl in the Silurian species changed to subtrapezoidal; the rounded ventral side became flat, and clearly separated from the flattened lateral sides, and the umbilical walls became steeper. The dorsoventral diameter of the whorl increased more rapidly in evolutionary younger species. The derivation of Boionautilus from Upper Ordovician Charactoceras Foerste, 1924 (Dzik 1984, p. 151, 155) is improbable as representatives of this genus (Foerste 1924, Strand 1934, Frey 1982) have a closely coiled, dorsoventrally compressed shell. Lateral sides converge to the dorsum and the cross section may also be reniform. Sutures are essentially straight laterally; the moderately wide siphuncle is located subventrally.

Species assigned. - Boionautilus tyrannus (Barrande, 1865) (= Nautilus complanatus Hisinger, 1831), Silurian, Wenlock, Ludlow to lower Přídolí; Sweden (Gotland); Boionautilus sternbergi (Barrande, 1865), mid-Silurian, upper Ludfordian, Bohemia (Prague Basin); Boionautilus sacheri (Barrande, 1865), Silurian, Ludlow, Ludfordian; Bohemia (Prague Basin). To this genus perhaps also belongs Boionautilus? holtianus (Blake, 1882) from the Silurian, Ludlow of England and perhaps Boionautilus? sp., Silurian, Ludlow, Sweden (Gotland). Boionautilus bohemicus (Barrande, 1865), Silurian, Př́idolí; Bohemia (Prague Basin); Germany (Harz); Great Britain (England) and Algeria (Ougarta Range). 

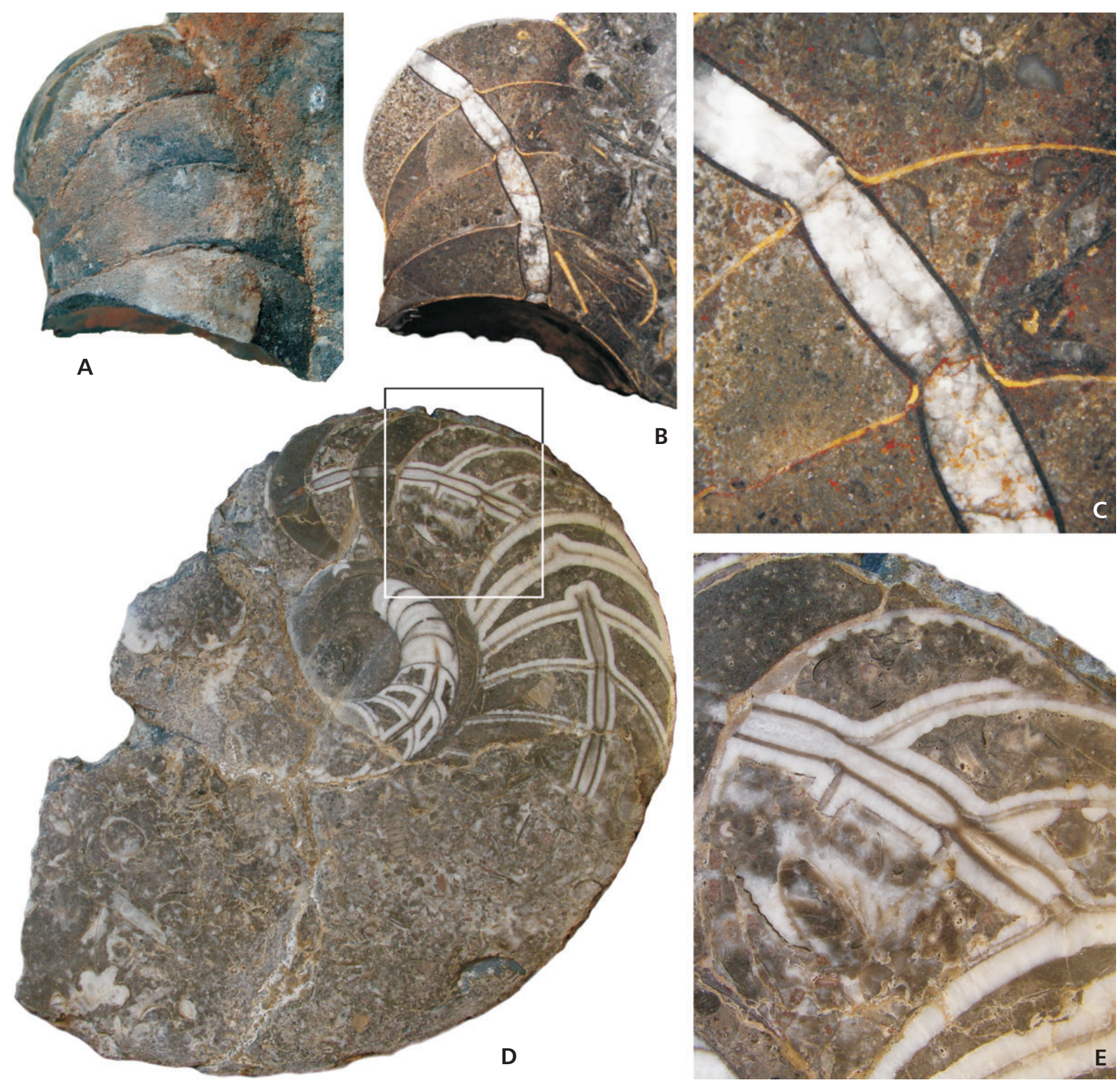

Figure 3. A-C - Boionautilus tyrannus (Barrande, 1865). NE Ougarta, Ougarta Range (Algeria), middle Ludlow, probably Ludfordian, Oued Ali Formation. $\bullet$ A - a part of phragmocone, lateral view, $\times 2.4$. $\bullet$ B - the same specimen, polished median section, $\times 2.4$. $\bullet \mathrm{C}-$ detail of siphuncle; different colour indicate differences in original composition of septa and connecting rings, $\times 8.2$, Mo 160870 . $\bullet$ D, E - Boionautilus sternbergi (Barrande, 1865). Praha-Lochkov (Bohemia), Ludlow, Ludfordian, Kopanina Formation (Horizon with Ananaspis fecunda). $\bullet$ D - polished median section, $\times 0.7$. $\bullet$ E - detail of siphuncle, $\times 2$. Coll. Schary, MCZ 135397 .

\section{Distribution of Boionautilus}

\section{Prague Basin (Bohemia)}

Barrande (1865-1867) described four species classified here as Boionautilus. Later Novák (1886) added one new species. The stratigraphical range of Boionautilus in the Prague Basin is from upper Ludlow to upper Př́ídolí (Turek \& Marek 1986, Manda in Kř́žz 1998).
The stratigraphically oldest species Boionautilus sternbergi (Barrande, 1865) occurs in the upper Ludfordian cephalopod limestone of the Kopanina Formation, the horizon with Ananaspis fecunda, P. latilobus Zone. The species is known from several localities, namely Praha-Lochkov, Praha-Malá Chuchle, Praha-Vyskočilka, Praha-Velká Chuchle, Praha-Butovice, Praha-Slivenec, Kosoř, Kosov Quarry near Beroun. The species Nautilus alinae Novák, 1886 was based on a single specimen repre- 


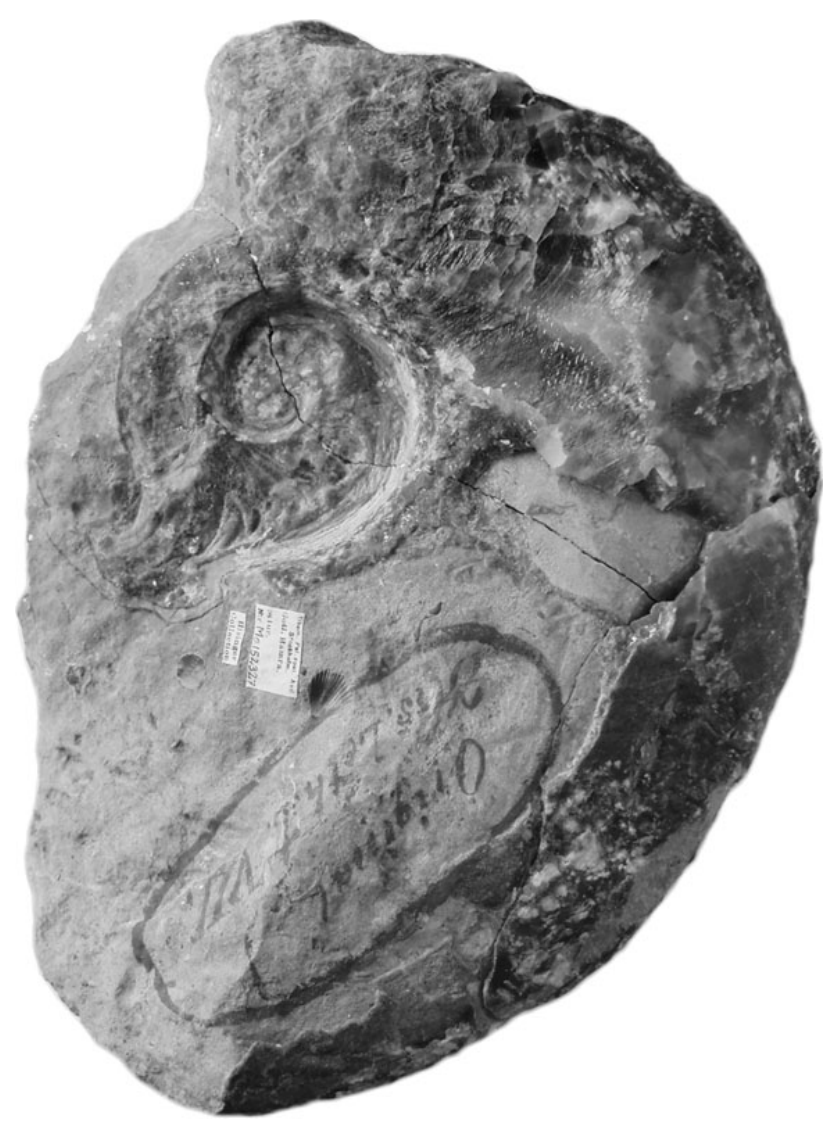

Figure 4. Boionautilus tyrannus (Barrande, 1865). Hamra, Gotland (Sweden), Ludfordian, Hamra beds. Holotype of Nautilus complanatus Hisinger, 1831 illustrated by Hisinger (1831, pl. 6 and 1837, pl. 7, fig. 1). Mo $152327, \times 0.5$.

sented by part of the whorl of an adult coming from the locality Praha-Velká Chuchle. The holotype of Nautilus alinae differs from the preceding species especially in the slower increase of the dorsoventral length and moderately wide siphuncle with inflated connecting rings. Several well-preserved specimens of B. sternbergi (e.g., NHM 1876/B 0009/0478, fig. 2), however, display very similar morphology. Therefore, Nautilus alinae is supposed a younger synonym of $B$. sternbergi.

The markedly smaller and ribbed species Boionautilus sacheri (Barrande, 1865) occurs also in the cephalopod limestone of the upper part of the Kopanina Formation. It ranges from the upper part of the Ananaspis fecunda Horizon, $P$. latilobus Zone, Ludfordian up to the lowermost part of the Prionopeltis archiaci Horizon, M. fragmentalis Zone, Ludfordian [localities Praha-Velká Chuchle, Praha-Lochkov, Praha-Butovice (Pod hradištěm) and Kosov Quarry near Beroun].

Boionautilus tyrannus (Barrande, 1865) occurs in the cephalopod limestone of the uppermost Kopanina Formation in the Prague area. The oldest specimens were found in the lower Prionopeltis archiaci Horizon, Monograptus fragmentalis Biozone, Ludlow while youngest in the P. ultimus Biozone, lowermost Přídolí; localities Praha-Lochkov (Nad ubikacemi, U topolů, Orthocérový lůmek), Praha-Malá Chuchle-Vyskočilka, Praha-Velká Chuchle, Praha-Slivenec, Kosoř, and Zadní Kopanina.

The stratigraphically youngest species Boionautilus bohemicus (Barrande, 1865) are virtually restricted to the cephalopod limestone of the upper Přídolí, M. transgrediens Zone; localities Praha-Dvorce, Karlštejn-Třebáňská stráň slope (western margin, Barrande's pits), Zadní Kopanina and Dlouhá hora near Beroun.

Blake (1882) compared fragmentary material from Britain with Barrande's (1865) illustrations and synonymised the two stratigraphically youngest successive species "Nautilus" bohemicus and "N." tyrannus. Although differences between these two species may be not well pronounced, an evolutionary trend expressed in changes of the shell shape is clear. B. sacheri (Barrande, 1865) was interpreted as synonymous with B. tyrannus (Barrande, 1865) by Dzik (1984). However, the shell of $B$. sacheri (Barrande, 1865) is much smaller in all known specimens (diameter of full-grown shells does not exceed $12 \mathrm{~cm}$ ) and bears characteristic ribbing on the surface. The embryonic shell is less curved. The very slightly involute shell of $B$. tyrannus (Barrande, 1865) may reach a diameter of about $25 \mathrm{~cm}$, whilst the venter and umbilical slopes are convex, and exceptionally, the ventral side is very narrow, sometimes almost sharp. The youngest species of this genus, i.e., B. bohemicum (Barrande, 1865) has a shell with flanks and ventral side more flattened - this feature already appearing in the second whorl. The dorsoventral diameter of the whorl increases more rapidly than in other species of the genus. Large embryonic shells in all these species are similar.

The fossil described by J. Barrande (1865-1867) under the name Nautilus? desideratus (pl. 34, figs 7, 8) coming from the Lochkov locality (upper Silurian) is the bivalve Dualina cf. longiuscula (Barrande, 1881), according to J. Kř́ž (personal communication, 2007).

\section{England (British Isles)}

Among the British Silurian cephalopods described and figured by Blake (1882), the specimen he determined as Nautilus bohemicus Barrande (pl. 27, figs 1, 2) surely belongs to Boionautilus. Blake reported the species from the Wenlock beds of Dudley and Ludlow beds of Malvern, Ledbury and Ludlow. The fragments that were at his disposal display characteristic features of B. tyrannus (see Blake 1882, p. 210) but he supposed this species to be conspecific with $B$. bohemicus. This opinion is not shared here and the specimen illustrated by Blake is assigned to Boionautilus tyrannus (Barrande, 1865). 
Another species Nautilus holtianus (Blake, 1882) illustrated by the author in pl. 28, fig. 1 might also belong to Boionautilus. The species was noted as occurring in the Ludlow beds at Stokesay and Ledbury. Unfortunately, the morphology of this species is poorly known, and because of the difficulty of matching the radial course of striae on the lateral surfaces, the taxonomic position of the species must remain questionable.

\section{Gotland (Sweden)}

Nautilus complanatus Hisinger, 1831, assigned here to Boionautilus, was one of the first coiled nautiloids mentioned from Gotland. Hisinger used the name for the first time in 1829 and two years later added a lithographed illustration of the specimen (Hisinger 1831). The species was briefly described by him in 1837; a very poor illustration of the holotype was added (Hisinger 1831, pl. 6). However, Nautilus complanatus Hisinger, 1831 is a junior homonym to Nautilus complanatus Sowerby, 1820. According to Lindström (1890) and Stridsberg (1985), the nautiloid described by Hisinger was renamed by d'Orbigny in "Paléontologie universelle" (1845-1847) as Nautilus Hisingerii. However, "Paléontologie universelle ..." (1845-1847) was never completed and there is no text about nautiloid cephalopods. The volume contains 55 plates, out of a numbered series 60 (Milner, letter communication). The plate with Nautilus Hisingerii is headed as plate 41 of "Paléontologie étrangere" on one side and plate 85 of "Paléontologie universelle" on the other side. The plate sequence in the book relates to the former title. Only the name "Nautilus Hisingerii d'Orb." without any other discussion is mentioned in the explanation to the illustration (Milner, letter communication). The name also has not been found neither in later published "Prodrome de Paléontologie stratigraphique universelle" (d'Orbigny 1850) nor in any other cephalopod lists of names and databases. Article 12 in the ICZN defines an "indication" which may be used to validate a taxon named before 1930; data published by d'Orbigny (1845-1847) are, however, inadequate. Due to these circumstances the name "Nautilus Hisingerii d'Orb." is considered as a nomen nudum. As this Gotland species is supposed to be identical with Boionautilus tyrannus (Barrande, 1865), this name was accepted here as a valid one.

The holotype by monotypy of Hisinger's Nautilus complanatus (= Boionautilus tyrannus Barrande, 1865) is specimen Mo 152327, refigured here as Fig. 4. It comes from the upper Ludlow, Ludfordian, Hamra beds, locality Hamra. This large specimen, preserved in grey argillaceous limestone, is incomplete, damaged and slightly deformed. The shell is slightly involute, laterally compressed, and the ventral surface is rounded. The reconstructed diameter of the shell is about $20 \mathrm{~cm}$. The surface is
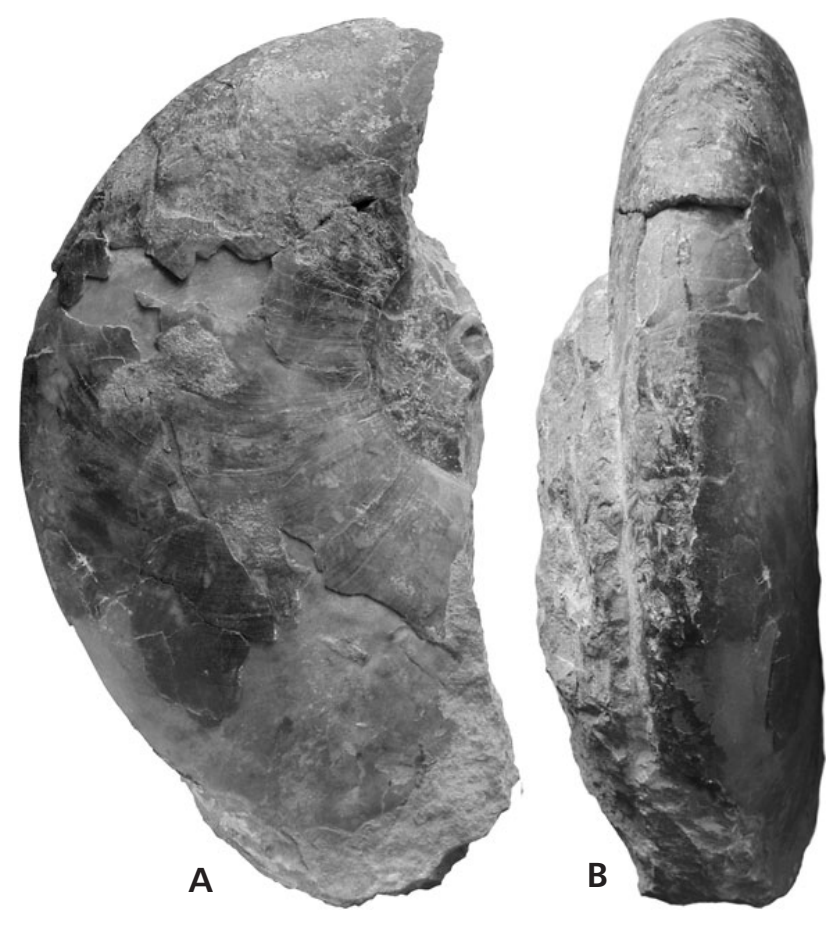

Figure 5. Boionautilus tyrannus (Barrande, 1865). Öja-Storviks kanal, Gotland (Sweden), Ludfordian, Hamra beds. • A - lateral view. $\bullet$ B - posterior view. Mo 59398, × 0.4 .

smooth, and the growth lines show a wide lateral sinus passing into a deep hyponomic sinus. Septa are densely spaced with a broad lateral sinus.

When describing a related and roughly contemporaneous species from Bohemia according to information given him by M. Angelin, J. Barrande (1867) treated this specimen as a representative of the genus Phragmoceras (Barrande 1867, pp. 130, 187; 1870, p. 35; 1877, p. 95). This generic assessment was, however, correctly denied by Lindström (1880).

Besides the holotype, additional specimens of Nautilus complanatus Hisinger, 1831 were later obtained from the following localities in Gotland: Hamra, Peteskanal Hamra Storkwiks kanal, Öja - Storviks kanal, Othem, Hoburg, Grötlingbo, Heligholm. Determination of the stratigraphic age of these specimens as upper Ludlow, is based on data published by Laufeld (1974), Larsson (1979), and Jeppsson \& Aldridge (2000). These specimens, predominantly preserved in the same type of rock as the holotype, represent fragments and parts of shells of different growth stages and complete information concerning morphology of $N$. complanatus (see Fig. 5A, B). As there are no reliable criteria to distinguish Nautilus complanatus Hisinger, 1831 from Boionautilus tyrannus (Barrande, 1865), and Hisinger's name of the species is invalid (see above), specimens of Boionautilus coming from the Silurian of Gotland are assigned to the latter species.

From the Hamra locality (Hamra beds, Ludlow, Ludfordian) also comes a specimen classified here as 


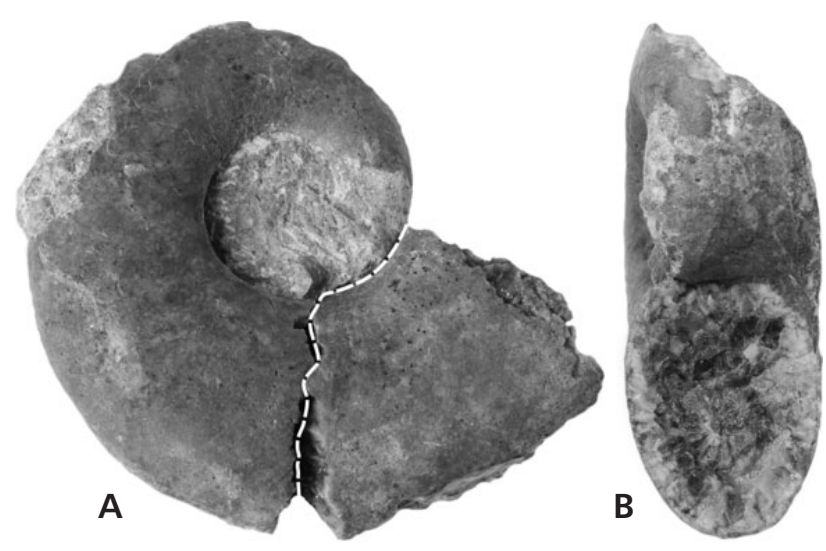

Figure 6. Boionautilus tyrannus (Barrande, 1865). • A, B - El Kseib, Ougarta Range (NE oasis El Kseib, SSW oasis Bani Abbas) (Algeria), Ludlow, probably Ludfordian, Oued Ali Formation. A part of phragmocone with preserved shell, lateral and frontal views (later without adapertural part of the shell indicated by broken line). S 4798, $\times 1$.

Boionautilus? sp. (Mo 59395 and Mo 59396). The median section shows well-preserved internal structures. Despite the fact that the shell is loosely coiled, the dorsal side is concave and the narrow siphuncle is slightly shifted dorsally.

\section{Harz, Wiedatales (Germany)}

Heritsch (1930) describing upper Silurian fossils from the locality Wiedatales in the Harz discussed and illustrated on pl. 33, figs 26 and 27 one specimen of Boionautilus bohemicus (Barrande, 1865) determined by him as Barrandeoceras bohemicum. The incomplete specimen representing an intermediate growth stage (diameter of the shell is $65 \mathrm{~mm}$ ) corresponds to this species. The associated fauna indicates the middle Přídolí Stage.

\section{Carnic Alps (Austria)}

Several specimens identified with Barrande's nautiloid species and belonging to Boionautilus were reported also from the Carnic Alps (Heritsch 1929, Histon 1999, Gnoli 2003). Shells illustrated on figs 759-762 of Heritsch (1929) were designated by him as Barrandeoceras sacheri Barrande, 1865 (explanation to plate p. 183) or $B$. cf. $s a$ cheri (see p. 74); the specimen illustrated on fig. 763 was classified as Barrandeoceras sp. by him. Histon (1999) rightly determined three of them as gastropods but determined the specimens figured as fig. 762 and 763 as Barrandeoceras? sp. However, these two specimens, which I had an opportunity to see in the palaeontological collection of the Geologisches Bundesanstalt, Vienna, cannot be juvenile growth stages of coiled nautiloids. The very small size and outer morphology indicate their systematic position within the gastropods. The occurrence of Boionautilus in the Carnic Alps has thus not been confirmed.

\section{North Africa, Ougarta Range (Algeria)}

The sequence of the Lower Palaeozoic in Algeria is well known owing to the intensive work of French geologists, especially Legrand (1966, 1985, 1994, 2003), and Ghienne et al. (2007). The cephalopod limestones from this area were compared with occurrences of the same facies in Central Bohemia. The Silurian cephalopod fauna from Algeria is still poorly known. Knowledge concerning this group was summarised by Gnoli (2003). The vast majority of cephalopods from this area belong to orthoceratoids representing either nekton or perhaps (according to Mutvei $2002 \mathrm{~b}$ ) plankton. Tarphycerids of the suborder Barrandeocerina have not hitherto been reported.

Barrandeocerina at my disposal comprise about 20 specimens collected by H. Mutvei in 1952 and one specimen found by palaeontologists from the National Museum, Prague in 1974. As these specimens show different preservation indicating two different localities, although probably not too distant from one-another, the material is discussed separately.

Locality Ougarta. - Tarphycerids collected by H. Mutvei come from the locality situated NE of Ougarta, Ougarta Range, in the Oued Ali Clay Formation. About 25 fragments (parts of whorls of different ontogenetic stages) are preserved in dark grey cephalopod limestone. Phragmocones are usually filled by coarse sparitic calcite, partially or totally destroying the internal structures. However, an exceptionally well-preserved specimen with phragmocone filled by dark micrite has also been found (Figs 3A-C, 7).

The height of the whorl of the largest but slender shell, the internal mould of the body chamber, is $57 \mathrm{~mm}$, the width $34 \mathrm{~mm}$. Although all specimens are considerably laterally compressed, variability of the width/length ratio of the whorl fluctuates from 0.70 to 0.85 . The specimens correspond morphologically to Boionautilus tyrannus (Barrande, 1865). In addition to these shells there are a few fragments showing a smaller increase of dorsoventral length, similar to B. sternbergi (Barrande, 1865). It is not clear whether both morphs were co-occurring or come from different stratigraphic horizons.

Specimen Mo 160870 (Fig. 3A-C) is a sagittal section of portion of a phragmocone. The adapertural length is $20 \mathrm{~mm}$; adapertural width $16 \mathrm{~mm}$. The siphuncle is situated slightly ventrad of the centre, and is narrow, orthochoanitic, with siphonal segments slightly expanding within camerae. The black colour of the thin-walled connecting rings contrasts with the brownish honey-coloured 
septal necks. A marked primary difference in chemical composition of these structures is therefore inferred; predominantly organic substance comprising connecting rings is expected. The phragmocone of another figured specimen (Mo 160868, Fig. 7) shows a siphuncle with inflated connecting rings.

Correlation with the cephalopod beds from the Prague Basin can only be done through a comparison with the stratigraphic range of Boionautilus tyrannus and associated bivalves. The stratigraphic range of B. tyrannus in the Prague Basin is from the uppermost Ludlow (Monograptus fragmentalis Biozone) to the lowermost Př́dolí (Pristiograptus ultimus Biozone). Bivalves determined by J. Kř́̌ž indicate a middle Ludlow age (Cardiola aff. docens Barrande, 1881 or Cardiola aff. agna Kříž, 1979, "Astarte" sp., Dualina sp. and Mytilarca sp.).

Locality El Kseib. - A single specimen was found by palaeontologists from the National Museum, Prague at the locality El Kseib, Ougarta Range (NE of oasis El Kseib, SSW of oasis Bani Abbas). The specimen is preserved in brownish biosparitic limestone and associated with bivalves and small, mostly fragmentary orthoconic nautiloids. The phragmocone is damaged with the first whorl either encased in rock or missing. The cross section of the whorl is elliptic and narrower ventrally, $w / 1=0.8$ ratio at shell diameter of $5.2 \mathrm{~cm}$. A very shallow impressed zone is present on the dorsal side, and the ventral side is convex. Surface sculpture displays the sinuous course of growth lines with a deep hyponomic sinus. Despite the coarse sparitic infilling of the phragmocone, the narrow siphuncle, positioned slightly ventrad of the centre, is preserved. The right half of one segment of the siphuncle, moderately expanding within a camera is visible. Septa are densely spaced; with seven camerae in a quarter of the whorl.

Conclusions concerning the correlation of the level within the cephalopod limestone level with similar levels in the Prague Basin, Bohemia (Kříž 1998) were predicted based on determination of bivalve associations obtained from a sample of rock separated from the specimen by J. Kř́žz. The bivalve association contains Algerina aff. algena Křǐž, 2008, Mytilarca aff. esuriens Barrande, 1881, Dualina sp., Cardiola aff. docens Barrande, 1881, Cardiola cf. conformis Barrande, 1881, Dualina longiuscula Barrande, 1881 and Butovicella aff. medea Kř́ž, 1969. The co-occurrence of the last four species is the most important for the conclusion concerning the age of Boionautilus from this locality and indicates that middle Ludfordian (Ludlow) is the most probable. This age is not in contradiction with the verified stratigraphic range of Boionautilus tyrannus in the Prague Basin. In addition, the orthocerid Aptychopsis figured by Turek (1978) comes from older, i.e. Wenlockian horizon of the same locality.
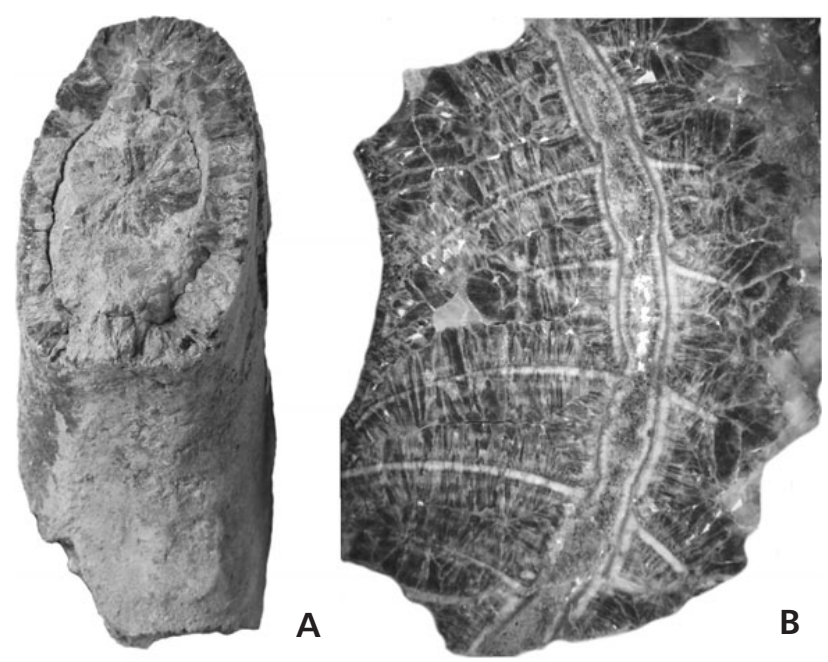

Figure 7. Boionautilus tyrannus (Barrande, 1865). • A, B - NE Ougarta, Ougarta Range, (Algeria), Oued Ali Formation - A - a part of phragmocone, frontal view, $\times 0.9$. $\bullet \mathrm{B}-$ the same specimen, polished median section. Mo $160868, \times 1.2$.

\section{Conclusions}

The genus Boionautilus gen. nov. is established for large Silurian tarphycerids originally assigned to the genus Nautilus and later reclassified by various cephalopod workers, usually with doubt, as Barrandeoceras Hyatt, 1884, Heracloceras Teichert, 1940, or Cumingsoceras Flower in Flower \& Kummel, 1950. The taxon was widely distributed in tropical and subtropical shallow seas of Avalonia, Baltica and Perunica, reaching also the somewhat colder waters of the North Gondwanan shelf, $c f$. distribution pattern of phragmoceratids (Manda 2007, 2008). Whereas the reported occurrence of these tarphycerids in the Carnic Alps (Heritsch 1929, Histon 1999) has not been confirmed, the species Boionautilus tyrannus (Barrande, 1865) has been verified among cephalopods coming from the $\mathrm{Ou}-$ garta Range, Algeria.

The transition from an evolute shell (gyroceracone at the beginning of the second whorl) with subelliptic cross section in the middle Ludlow species Boionautilus sternbergi (Barrande, 1865) to a slightly involute shell with subtrapezoidal cross section in the upper Př́idolí Boionautilus bohemicus (Barrande, 1865) is considered to be a clearly expressed evolutionary trend. Comparing end-members of this lineage, progressive shortening of gas chambers is apparent. The gradual change of shape improved the hydrodynamic properties of the shell, and in turn, the swimming ability of these nautiloids (Chamberlain 1981, Jacobs \& Chamberlain 1996). This is interpreted as an example of adaptive evolution (Kröger 2005). The short body chamber, ventrolateral position of retractor muscle scars, deep hyponomic sinus, wide geographic distribution and its occurrence in a variety of 
sedimentary facies indicate a nektonic mode of life for Boionautilus. Reproductive strategy was probably the same as in Nautilus with few, but well-developed offspring, as can be deduced from large curved embryonic shell in Boionautilus.

The imperfect coiling of the shell in Boionautilus sternbergi leads to a search for the ancestor of this genus amongst loosely coiled Late Ordovician tarphycerids closely related to Uranoceras? longitudinale (Angelin \& Lindström, 1880) (see Mutvei 1957) as being more likely than within the Upper Ordovician Charactoceras (see Dzik 1984).

There is very little information concerning the internal structure of connecting rings in Tarphycerida. Siphuncular structure studied in several specimens of the family Estonioceratidae shows that connecting rings in tarphycerids were originally composed of the same two layers as those in recent Nautilus - an outer spherulitic-prismatic layer and an inner glycoprotein (conchiolin) layer (Mutvei 2002a). Barrandeocerina have not been studied from this point of view. The striking differences in the colour of septa and connecting rings observed in some specimens of Boionautilus are remarkable. A high primary content of organic matter forming the connecting rings is supposed; a feature contrasting with our existing knowledge of their structure in Tarphycerina. Additional, more detailed investigation of these structures in other Barrandeocerina is necessary.

Despite certain differences in morphology, the similarity between Boionautilus and recent Allonautilus Ward \& Saunders, 1997 is striking and much more manifest than is the similarity between Devonian and recent representatives of the Nautilida. Due to the morphological and stratigraphical gaps during the Devonian, Boionautilus can hardly at present be accepted as an ancestor of Carboniferous nautilids. However, to trace ancestors of recent Nautilida amongst the Silurian Barrandeocerina (Dzik \& Korn 1992) is well founded.

\section{Acknowledgements}

The research was supported by the Czech Grant Agency through the project GAČR 2005/05/0875 and Ministry of Culture project DE06P04OMG009. The author thanks Fred Collier and Jessica Cundiff (Museum of Comparative Zoology, Harvard), Jan Bergström, Cristina Franzén, Jonas Hagström and Harry Mutvei (Swedish Museum of Natural History, Stockholm), Sven Stridsberg (University Lund), Andreas Kroh (Museum of Natural History, Vienna), Irene Zorn (Geological Survey of Austria, Vienna) for providing the material used in this study and other great help during my stay in mentioned institutions; Ladislav Zedník, and Antonín Čížek for some important specimens; Jiří Kříž (Czech Geological Survey, Prague) for advice concerning stratigraphy; Radvan Horný (National Museum, Prague) and two re- viewers, David H. Evans (Natural England, Peterborough) and Štěpán Manda (Czech Geological Survey, Prague) for critical reading of the manuscript; Bertrand Lefebvre (Université Claude Bernard, Lyon), Didier Merle (Museum d'Histoire Naturelle de Paris), Andrew Milner (Natural History Museum, London) and Pavel Štys (Charles University, Prague) for kind help with solving one nomenclatorical problem; Nigel Hughes (University of California) for improving English; and Jan Sklenár and Radek Labuta (National Museum, Prague) for technical help.

\section{References}

AGASSIZ, L. 1847. An introduction to the study of natural history, in a series of lectures delivered in the hall of the College of Physicians and Surgeons. 58 pp. Greeley \& McElrath, New York.

ANGELIN, N.P. \& LINDSTRÖM, G. 1880. Fragmenta silurica e dono Caroli Henrici Wegelin. 60 pp., 20 pls. Samson \& Wallin, Holmiae.

BASSE, É. 1952. Sous-classe des Nautiloidea, 463-521. In Piveteau, J. (ed.) Traité de Paléontologie, Tome II, Problèmes d'adaptation et de phylogénèse Brachiopodes, Chétognathes, Annélides, Géphyriend, Mollusques. Masson et Cie, Paris.

BARRANDE, J. 1865-1877. Systême silurien du centre de la Bohême, I ère partie: Recherches Paléontologiques, Vol. II, Classe de Mollusques, Ordre des Céphalopodes. 1865, ser. 6, pls 1-107; 1866, ser. 7, pls 108-244; 1867, ser. 1, 712 pp.; 1868, ser. 8, pls 245-350; 1870, ser. 2, 266 pp., ser. 9, pls 351-460; 1874, ser. 3, 804 pp.; 1877, ser. 4, 742 pp., ser. 5, 743 pp., supplement 1, 297 pp., supplement 2, pls 461-544. Published by the author, Prague $\&$ Paris.

BARRANDE, J. 1881. Systême silurien du centre de la Bohême. İ̀re partie: Recherches Paléontologiques, Classe des Mollusques, ordre des Acéphalés. 6. 342 pp., 356 pls. Prague \& Paris.

BILLINGS, E. 1859. Fossils of the calciferous sandrock, including those of a deposit of white limestone at Mingan, supposed to belong to the formation. Canadian Naturalist 4, 345-367.

BLAKE, J.F. 1882. A monograph of the British fossil Cephalopoda, Part I, Introduction and Silurian species. 248 pp. John Van Voorst, London.

CHAMBERLAin, J.A., JR. 1981. Hydromechanical design of fossil cephalopods, 290-336. In HOUSE, M.R. \& SENIOR, J.R. (eds) The Ammonoidea. The evolution, classification, mode of life and geological usefulness of a major fossil group. The Systematic Association Special Volume No. 18. Academic Press, London, New York, Toronto, Sydney \& San Francisco.

DAVIS, R.A. \& MAPES, R.H. 1996. Phyllum Mollusca, class Cephalopoda, 166-175. In FELDMAN, R.M. \& HACKATHORN, M. (eds) Fossils of Ohio. Ohio Division of Geological Survey Bulletin 70.

DZIK, J. 1984. Phylogeny of the Nautiloidea. Palaeontologia Polonica 45, 1-219.

DZIK, J. \& KORN, D. 1992. Devonian ancestors of Nautilus. Paläontologische Zeitschrift 66, 81-98.

FLOWER, R.H. 1984. Bodeiceras, a new mohawkian oxycone, with 
revision of the older Barrandeoceratida and discussion of the status of the order. Journal of Paleontology 58(6), 1372-1379.

FLOWER, R.H. \& KUMMEL, B. 1950. A classification of the Nautiloidea. Journal of Paleontology 24(5), 603-616.

FOERSTE, A.F. 1924. Notes on American Paleozoic cephalopods. Denison University Bulletin, Journal of the Scientific Laboratories 20, 193-268.

FOERSTE, A.F. 1925. Notes on cephalopod genera; chiefly coiled forms. Denison University Bulletin, Journal of the Scientific Laboratories 21, 1-69.

FOERSTE, A.F. 1926. Actinosiphonate, trochoceroid and other cephalopods. Denison University Bulletin, Journal of the Scientific Laboratories 21, 285-383.

FREY, M.F. 1982. Upper Ordovician (Harjuan) nautiloid cephalopods from the Boda Limestone of Sweden. Journal of Paleontology 56(5), 1274-1292.

Ghienne, J.F., Boumendjel, K., Paris, F., Videt, B., RACHEBOEUF, P.R. \& SALEM, H.A. 2007. The Cambrian-Ordovician succession in the Ougarta Range (western Algeria, North Africa) and interference of the late Ordovician glaciation on the development of the Lower Palaeozoic transgression on northern Gondwana. Bulletin of Geosciences 82(3), 183-214. DOI 10.3140/bull.geosci.2007.03.183.

GNOLI, M. 2003. Northern Gondwanan Siluro-Devonian palaeogeography assessed by cephalopods. Palaeontologica Electronica 5(2), http://palaeo-electronica.org, 1-19.

HerITSCH, F. 1929. Faunen aus dem Silur der Ostalpen. Abhandlungen der Geologischen Bundesanstalt 23(2), 1-181.

HERITSCH, F. 1930. Die obersilurische Fauna des Wiedatales im Harz. Jahrbuch der Preussischen Geologischen Landesanstalt zu Berlin für das Jahr 1929, Band L, Teil 2, 514-580.

HISINGER, W. 1829. Esquisse d'un tableau des pétrifications de la Suède, distribuées en ordre systématique. 27 pp. P.A. Norstedt et fils, Stockholm.

HisingeR, W. 1831. Anteckningar Physik och Geognosie under Resor uti Sverige och Norrige, V. Stockholm. Bidrag till Sveriges Geognosie Fortsättning af Anteckningar i Physik of Geognosie m.m. Tilläggningar och Register 5, 112 pp.

HISINGER, W. 1837. Lethaea Suecica seu petrificata Sueciae, iconibus et characteribus illustrata. 124 pp., 39 pls. P.A. Norstedt et filii, Holmiae.

HistON, k. 1998. Die Nautiloiden-fauna aus dem Silur der Karnischen Alpen. Geologische und Paläontologische Mitteilungen 23, 105-115.

Histon, K. 1999. Revision of the Silurian nautiloid cephalopods from the Carnic Alps (Austria) - The Heritsch (1929) collection in the Geological Survey of Austria. Abhandlungen der Geologischen Bundesanstalt 56(1), 229-258.

HoRNÝ, R. 1965. Třída Cephalopoda - hlavonožci, 431-454. In ŠPINAR, Z. (ed.) Systematická paleontologie bezobratlých. Academia, Praha.

HyATT, A. 1883-1884. Genera of fossil cephalopods. Boston Society Natural History Proceedings 22, 273-338.

HyatT, A. 1894. Phylogeny of an acquired characteristic. Proceeding of the American Philosophical Society 32, 349-647, pls $1-14$.
HyATT, A. 1900. Order 1. Nautiloidea, 513-535. In ZITTEL, K.A. Text-book of Paleontology, Vol. 1. Macmillan \& Co., New York.

JACOBS, D.K. \& CHAMBERLAIN, J.A., JR. 1996. Buoyancy and hydrodynamics in ammonoids, 169-224. In LANDMAN, N.H., TANABE, K. \& DAVIS, R.A. (eds) Ammonoid Paleobiology. Plenum Press, New York \& London.

JEPPSSON, L. \& ALDRIDGE, R.J. 2000. Ludlow (late Silurian) oceanic episodes and events. Journal of the Geological Society of London 157, 1137-1148.

KRÖGER, B. 2005. Adaptive evolution in Paleozoic coiled cephalopods. Paleobiology 31(2), 253-268.

DOI 10.1666/0094-8373(2005)031[0253:AEIPCC]2.0CO;2

KŘíž, J. 1969. Genus Butovicella gen. n. in the Silurian of Bohemia (Bivalvia). Sborník geologických věd, R̆ada P - Paleontologie 10, 105-139.

KŘíž, J. 1979. Silurian Cardiolidae (Bivalvia). Sborník geologických vĕd, Paleontologie 22, 1-157.

KŘíž, J. 1998. Recurrent Silurian-lowest Devonian cephalopod limestones of Gondwanan Europe and Perunica, 183-198. In LANDING, E. \& JOHNSON, M.E. (eds) Silurian cycles: Linkages of dynamic stratigraphy with atmospheric, oceanic, and tectonic changes. New York State Museum Bulletin 491.

Kř́ǐz, J. 2008. Algerina gen. nov. (Bivalvia, Nepiomorphia) from the Silurian of North Gondwana margin (Algeria), periGondwanan Europe (France, Italy), Perunica (Prague Basin, Bohemia) and Siberian Plate (Tajmyr Basin, Russia). Bulletin of Geosciences 83(1), 79-84.

DOI 10.3140/bull.geosci.2008.01.079

LARSSON, K. 1979. Silurian tentaculitids from Gotland and Scania. Fossils and Strata 11, 1-180.

LAUfELD, S. 1974. Reference localities for Palaeontology and Geology in the Silurian of Gotland. Sveriges Geologiska Undersökning, Ser. CNR 705, Avhandlingar och Uppsatser, Ärsbok 68, 1-172.

LEGRAND, P. 1966. Précisions biostratigraphiques sur l'Ordovicien inférieur et le Silurian des chaînes d'Ougarta (Sahara Algérien). Compte Rendu Sommaire des Séances de la Société Géologique de France 7, 243-245.

LEGRAND, P. 1985. Lower Paleozoic rocks of Algeria, 5-89. In Holland, C.H. (ed.) Lower Paleozoic of north-western and west central Africa. John Wiley \& Sons Ltd., Chichester.

LEGRAND, P. 1994. Sea level and faunal change during the late Wenlock and earliest Ludlow (Silurian): A point of view from the Algerian Sahara. Historical Biology 7, 271-290.

LEGRAND, P. 2003. Silurian stratigraphy and paleogeography of the northern African margin of Gondwana, 59-104. In LANDING, E. \& JOHNSON, M.E. (eds) Silurian lands and seas. Paleogeography outside of Laurentia. New York State Museum Bulletin 493.

LINDSTRÖM, G. 1890. The Ascoceratidae and the Lituitidae of the upper Silurian formation of Gotland. Kongliga Svenska Vetenskaps-Akademiens Handlingar 23(12), 1-54, 7 pls.

LINNAEUS, C. 1758. Systema Naturae, $10^{\text {th }}$ edition. 824 pp. Laurentii salvii, Holmiae.

MANDA, Š. 2007. New Silurian nautiloids Phragmoceras Broderip, 1839 and Tubiferoceras Hedström, 1917, from the 
Prague Basin (Bohemia). Bulletin of Geosciences 82(2), 119-131. DOI 10.3140/bull.geosci.2007.02.119

MANDA, Š. 2008. Palaeoecology and palaeogeographic relations of the Silurian phragmoceratids (Nautiloidea, Cephalopoda) of the Prague Basin (Bohemia). Bulletin of Geosciences 83(1), 39-62. DO1 10.3140/bull.geosci.2008.01.039

MANDA, Š. \& KŘÍŽ J. J. 2007. New cephalopod limestone horizon in the Ludlow (Gorstian, lower L. scanicus Biozone) of the Prague Basin (Bohemia, Perunica). Bollettino della Società Palaeontologica Italiana 46(1), 33-45.

MEEK, F.B. 1871. Descriptions of new species of invertebrate fossils from the Carboniferous and Devonian Rocks of Ohio. Proceedings of the Academy of Natural Sciences Philadelphia, 57-93.

MUTVEI, H. 1957. On the relations of the principal muscles to the shell in Nautilus and some fossil nautiloids. Arkiv för Mineralogi och Geologi 2(10), 219-254.

MutVeI, H. 2002a. Connecting ring structure and its significance for classification of the ortoceratoid cephalopods. Acta Palaeontologica Polonica 47(1), 157-168.

MUTVEI, H. 2002b. Nautiloid systematics based on siphuncular structure and position of muscle scars. Abhandlungen der Geologischen Bundesanstalt 57, 379-392.

NovÁK, O. 1886. Zur Kenntniss se Fauna der Etage F-f1 in der Palaeozoischen Schichtengruppe Böhmens. Sitzungsberichte der Keiserlichen Böhmischen Gesellschaft der Wissenschaften 1886, 1-27.

ORBIGNY, A.D. D' 1845-1847. Paléontologie universelle des coquilles et des mollusques, vol. 1. 392 pp., 55 pls. Masson, Paris.

ORBIGNY, A.D. D’ 1850-1852. Prodrome de paléontologie stratigraphique universelle des animaux mollusques \& rayonnés, vol. 1-3. 1017 pp. Masson, Paris.

SOWERBY, J. 1818-1822. The mineral conchology of Great Britain; or coloured figures and descriptions of those remains of testaceous animals or shells which have been preserved at various times and depths in the Earth. Continued by James de Carle Sowerby, vol. 5. 168 pp. Published privately, London.

STRAND, T. 1934. The Upper Ordovician cephalopods of the Oslo area. Norsk Geologisk Tidsskrift 14(1), 1-117.
STRIDSBERG, S. 1985. Silurian oncocerid cephalopods from Gotland. Fossils and Strata 18, 1-65.

STRIDSBERG, S. \& TUREK, V. 1997. A revision of the Silurian nautiloid genus Ophioceras Barrande. Geologiska Föreningen Förhandlingar 119, 21-36.

SWEET, W. 1964. Nautiloidea-Barrandeocerida, 368-382. In MOORE, R.C. (ed.) Treatise on invertebrate paleontology, part K, Mollusca 3. The University of Kansas Press, Lawrence.

TEICHERT, C. 1940. Contributions to nautiloid nomenclature. Journal of Paleontology 14(6), 590-597.

TUREK, V. 1972. O systematickém postavení rodu Ophioceras Barrande, 1865 (Nautiloidea). [On the systematic position of the genus Ophioceras Barrande, 1865 (Nautiloidea)]. Časopis Národního muzea, Oddíl př́rodovědný 141, 30-32.

TUREK, V. 1975. Genus Kosovoceras gen. n. from the Middle Bohemian Silurian (Nautiloidea). Sborník geologických věd, Paleontologie 17, 5-44.

TUREK, V. 1976. Magdoceras gen. $\mathrm{n}$. and Inclytoceras gen. $\mathrm{n}$. from the Silurian of Central Bohemia (Nautiloidea, Barrandeoceratida). Časopis pro mineralogii a geologii 21(2), 137-145.

TUREK, V. 1978. Biological and stratigraphical significance of the Silurian nautiloid Aptychopsis. Lethaia 11, 127-138. DOI 10.1111/j.1502-3931.1978.tb01297.x

TUREK, V. \& MAREK, J. 1986. Notes on the phylogeny of the Nautiloidea. Paläontologische Zeitschrift 60 (3/4), 245-253.

ULRICH, E.O., FOERSTE, A.F., MILLER, A.K. \& FURNISH, W.M. 1942. Ozarkian and Canadian Cephalopoda. Part I: Nautilicones. Geological Society of America, Special Paper 37, 1-157.

WARD, P. \& SAUNDERS, W.B. 1997. Allonautilus: a new genus of living nautiloid cephalopod and its bearing on phylogeny of the Nautilida. Journal of Paleontology 71(6), 1054-1064.

WINCHELL, A. \& MARCY, O. 1866. Enumeration of fossils collected in the Niagara Limestone at Chicago, Illinois; with descriptions of several new species. Boston Society of Natural History, Memoirs 1865(1), 81-114.

WhitEAVES, J.F. 1906. The Canadian species of Plectoceras and Barrandeoceras. Geological Survey of Canada, Palaeozoic fossils 3(4), 299-325.

ZHURAVLEVA, F.A. 1974. Devonskie nautiloidei. Otrjady Oncocerida, Tarphycerida and Nautilida. Trudy Paleontologicheskogo Instituta 142, 1-160. 